\title{
Hubungan Riwayat Penyakit Diare dan Praktik Higiene dengan Kejadian Stunting pada Balita Usia 24-59 Bulan di Wilayah Kerja Puskesmas Simolawang, Surabaya
}

\section{The Relations Between Diarrheal Disease History and Hygiene Practices with Stunting Incidences Among Children Aged 24-59 Months in The Work Area of Puskesmas Simolawang, Surabaya}

\author{
Chamilia Desyanti*1 ${ }^{1}$, Triska Susila Nindya ${ }^{2}$
}

\begin{abstract}
ABSTRAK
Latar belakang: Stunting pada anak merupakan dampak yang bersifat kronis dari konsumsi diet berkualitas rendah yang terus menerus dan didukung oleh penyakit infeksi dan masalah lingkungan. Praktik higiene yang buruk dapat menyebabkan balita terserang penyakit diare yang nantinya dapat menyebabkan anak kehilangan zat-zat gizi yang penting bagi pertumbuhan.

Tujuan: Penelitian ini bertujuan untuk menganalisis hubungan riwayat penyakit diare dan praktik higiene dengan kejadian stunting pada balita usia 24-59 bulan.

Metode: Penelitian menggunakan desain kasus kontrol. Sampel kasus adalah balita stunting dan sampel kontrol adalah balita tidak stunting di wilayah kerja Puskesmas Simolawang dengan jumlah masing-masing 33. Hubungan dan besar risiko antara variabel diuji menggunakan Chi Square dan Odd Ratio.

Hasil: Sebagian besar anak pada kelompok stunting sering mengalami diare $(72,7 \%)$ sedangkan pada kelompok tidak stunting jarang mengalami diare $(57,6 \%)$. Sebagian besar pengasuh pada kelompok stunting memiliki praktik higiene yang buruk $(75,8 \%)$, sedangkan pada kelompok tidak stunting memiliki praktik higiene yang baik $(60,6 \%)$. Riwayat penyakit diare $(p=0,025, O R=3,619)$ dan praktik higiene $(p=0,006, O R=4,808)$ memiliki hubungan yang signifikan dengan kejadian stunting. Kesimpulan: Riwayat diare yang terjadi secara sering dalam 3 bulan terakhir dan praktik higiene yang buruk meningkatkan risiko sebesar 3,619 dan 4,808 kali terhadap kejadian stunting pada balita usia 24-59 bulan. Hal yang dapat disarankan adalah adanya pemantauan terkait riwayat penyakit infeksi pada balita oleh posyandu setempat dan diadakan penyuluhan terkait dengan pola asuh pada anak, khususnya praktik higiene, karena pola asuh yang baik dapat berdampak kepada status gizi yang lebih baik.
\end{abstract}

Kata Kunci: stunting, balita, penyakit diare, praktik higiene 


\begin{abstract}
Background: Stunting among children is a chronic impact of a long-term low quality dietary intake accompanied by infectious diseases and environmental issues. Bad hygiene practices can lead to diarrheal disease that can make children loss some essential nutrients for body growth.

Objectives: This research aimed to analyze the relations between history of diarrheal disease and hygiene practices with stunting incidences among children aged 24-59 months.

Methods: This research was designed with case control. The case was stunting children and the control was non-stunting children in the work area of Puskesmas Simolawang with sample of 33 children each. The relation between variables was tested using Chi Square and Odd Ratio.

Results: The majority of children in stunting group had the diarrheal disease frequently (72.7\%), whereas children in non stunting group had the diarrheal disease rarely (57.6\%). Most of children caretaker in stunting group had bad hygiene practices (75.8\%), whereas children caretaker in non stunting group had good hygiene practices (60.6\%). The history of diarrheal disease ( $p=0.025$, $O R=3.619)$ and hygiene practices $(p=0.006, O R=4.808)$ had significant relation with stunting. Conclusion: The frequent diarrheal diseases and poor hygiene practices increase the risk of stunting 3.619 and 4.808 times among children aged 24-59 months. It can be recommended that there should be a monitoring of infectious disease among children held by Intergrated Health Post and should be held an education related to parenting styles, especially hygiene practices, because a good parenting styles could lead to a better nutritional status.
\end{abstract}

Keywords: stunting, children, diarrheal disease, hygiene practices

\footnotetext{
*Koresponden:

chamiliadesyanti@gmail.com

${ }^{1}$ Departemen Gizi Kesehatan, Fakultas

Kesehatan Masyarakat-Universitas Airlangga
} 


\section{PENDAHULUAN}

Stunting merupakan gangguan pertumbuhan tinggi badan atau panjang badan seorang anak dimana pertumbuhan tinggi badan tersebut tidak sesuai seiring dengan bertambahnya usia. Stunting pada anak merupakan hasil jangka panjang konsumsi yang bersifat kronis diet berkualitas rendah yang dikombinasikan dengan morbiditas, penyakit infeksi, dan masalah lingkungan $^{[1]}$. Selain disebabkan oleh gizi buruk, faktor risiko lain penyebab stunting menurut WHO ialah kejadian BBLR (Berat Badan Lahir Rendah), riwayat pemberian ASI eksklusif, riwayat penyakit infeksi, kualitas dan jumlah MP-ASI, dan praktik higiene ${ }^{[2]}$. Stunting ini merupakan keadaan tidak normal tubuh yang disebabkan oleh lebih dari satu faktor (multifaktor), yang berarti dibutuhkan satu faktor utama dan faktor-faktor penyebab lainnya untuk sampai terjadi stunting ${ }^{[3]}$.

Penurunan angka stunting atau postur tubuh pendek menjadi target internasional 2025 dan menjadi salah satu output bidang kesehatan dari Sustainable Developmet Goals (SDGs), yang merupakan program kelanjutan dari Millennium Development Goals $(\mathrm{MDGs})^{[4]}$. Prevalensi stunting di Indonesia berdasarkan Riskesdas 2013 adalah sebesar $37,2 \%$, kemudian jika dibandingkan dengan persentase tahun 2010 (35,6\%) dan 2007 $(36,8 \%)$, prevalensi tersebut mengalami peningkatan ${ }^{[5]}$.

Salah satu faktor penyebab terjadinya stunting adalah penyakit diare.Penyakit infeksi yang disertai diare dan muntah dapat menyebabkan anak kehilangan cairan serta sejumlah zat gizi ${ }^{[6]}$. Seorang anak yang mengalami diare akan terjadi malabsorbsi zat gizi dan hilangnya zat gizi dan bila tidak segera ditindaklanjuti dan diimbangi dengan asupan yang sesuai makan terjadi gagal tumbuh ${ }^{[7]}$. Jumlah kejadian diare berdasarkan data profil kesehatan Indonesia tahun 2015 adalah sebanyak 5.405.235 dan kasus yang ditangani adalah $74 \%$ dari total kasus ${ }^{[8]}$. Penelitian terkait penyakit diare dengan stunting sudah banyak dilakukan, baik di dalam maupun luar negeri, seperti oleh Hien dkk yang memperoleh hasil bahwa tidak ada hubungan yang signifikan antara penyakit diare dengan kejadian stunting pada balita, namun penelitian serupa juga dilakukan oleh Dewi dkk dengan hasil yang tidak sejalan yaitu riwayat penyakit infeksi, termasuk diare, merupakan salah satu faktor risiko yang dominan terhadap kejadian stunting ${ }^{19,21}$. Berdasarkan data profil kesehatan Kota Surabaya tahun 2015, terdapat sedikitnya 60.960 kasus diare di Kota Surabaya, dimana sekitar 700 diantaranya terdapat di Puskesmas Simolawang dan jumlah kejadian diare meningkat pada tahun 2015 menuju $2016^{8}$.

Faktor penyebab lainnya adalah praktik higiene. Balita yang mengonsumsi makanan sebagai hasil dari praktik higiene yang buruk dapat meningkatkan risiko anak tersebut terkena penyakit infeksi. Penyakit infeksi ini biasa ditandai dengan gangguan nafsu makan dan muntah-muntah sehingga asupan balita tersebut tidak memenuhi kebutuhannya. Kondisi seperti ini yang nantinya akan berimplikasi buruk terhadap pertumbuhan anak $^{[9]}$. Praktik higiene dan sanitasi lingkungan sangat berkaitan dengan penyakit diare terutama di negara-negara berkembang, sehingga menimbulkan malnutrisi dan dampak seperti gizi kurang, stunting, hingga kejadian gizi buruk ${ }^{[10]}$. Penelitian terkait praktik higiene dengan kejadian stunting sudah dilakukan oleh Rah dan tim di negara India ${ }^{28}$. Berdasarkan profil kesehatan Kota Surabaya tahun 2015 menunjukkan bahwa persentase rumat tangga (RT) yang berperilaku hidup bersih dan sehat (PHBS) di Surabaya adalah sebanyak $71,9 \%$, sedangkan di Puskesmas Simolawang adalah sebesar $66,94 \%$. Hal ini menunjukkan bahwa persentase PHBS di Puskesmas Simolawang lebih rendah jika dibandingkan persentase Surabaya ${ }^{8}$.

Penelitian terkait dengan hubungan penyakit diare dengan stunting sudah banyak dilakukan dan hubungan praktik higiene dengan stunting masih belum banyak dilakukan di Indonesia. Berdasarkan uraian diatas, penulis tertarik untuk meneliti lebih jauh hubungan antara riwayat penyakit diare dan pemberian ASI eksklusif serta praktik higiene dengan kejadian stunting pada balita usia 24-59 bulan di wilayah kerja Puskesmas Simolawang Surabaya tahun 2017. 


\section{METODE}

Penelitian ini merupakan penelitian observasional analitik dengan menggunakan desain penelitian kasus kontrol. Populasi yang digunakan dalam penelitian ini adalah semua anak usia 24-59 bulan yang berada di wilayah kerja Puskesmas Simolawang, Surabaya. Sampel kasus adalah balita stunting dan sampel kontrol adalah balita tidak stunting di wilayah kerja Puskesmas Simolawang dengan jumlah masing-masing 33 balita, yang diperoleh dengan menggunakan rumus Lemeshow untuk desain penelitian kasus kontrol. Balita dipilih dengan menggunakan simple random sampling untuk kelompok kasus dan dilakukan matching dengan kelompok kasus terkait usia dan jenis kelamin untuk kelompok kontrol. Dalam menetukan kelompok stunting, dilakukan skrining data balita di Puskesmas Simolawang yang meliputi besar z-score dan kemudian balita yang mengalami stunting akan dipilih secara acak. Sedangkan dalam menentukan kelompok kontrol, dilakukan persamaan perbandingan usia dan jenis kelamin balita dengan kelompok kasus untuk meminimalisasi adanya bias yang terjadi. Variabel bebas yang digunakan dalam penelitian ini adalah riwayat penyakit diare dan praktik higiene, sedangkan variabel terikat ialah kejadian stunting. Teknik pengumpulan data dilakukan dengan cara pengumpulan data primer yaitu pengukuran tinggi badan dan wawancara. Tinggi badan balita diukur menggunakan microtoise dengan kapasitas panjang mencapai $200 \mathrm{~cm}$ atau $2 \mathrm{~m}$ dan derajat ketelitian sebesar $0,1 \mathrm{~cm}$. Apabila hasil z-score balita menunjukkan < -2 SD maka balita tersebut tergolong stunting, sedangkan bila hasil z-score menunjukkan $\geq-2$ SD maka balita tersebut tergolong tidak stunting. Wawancara terkait riwayat diare menggunakan kuesioner dengan ibu atau pengasuh sebagai sasaran. Berdasarkan Depkes tahun 2004, apabila dalam 3 bulan terakhir balita menderita diare $\leq 2$ kali maka tergolong diare jarang, sedangkan bila menderita diare $>2$ kali maka tergolong sebagai diare sering ${ }^{[30]}$. Wawancara terkait praktik higiene menggunakan kuesioner yang terdiri dari 36 pertanyaan yang harus dilengkapi dengan pengasuh sebagai sasaran. Setiap pertanyaan pada kuesioner bernilai 1 (satu) jika sesuai dengan yang dianjurkan, dan bernilai 0 (nol) jika tidak sesuai. Bila hasil akhir kuesioner masing-masing pengasuh adalah $\leq$ 19 maka tergolong sebagai higiene buruk, sedangkan > 19 maka tergolong higiene baik $^{[11]}$.

Hubungan antara variabel bebas dan terikat dianalisis menggunakan uji Chi Square $(\mathrm{p}<0,05)$ dan uji OR digunakan untuk mengetahui besar risiko dari masing-masing variabel yang saling berhubungan. Penelitian ini telah disetujui oleh Komisi Etik Penelitian Kesehatan Fakultas Kesehatam Masyarakat Universitas Airlangga dengan nomor etik 216KEPK.

\section{HASIL DAN PEMBAHASAN}

Karakteristik orang tua yang diteliti pada penelitian ini meliputi pendidikan, pekerjaan, dan pendapatan keluarga, sedangkan karakteristik balita meliputi jenis kelamin dan usia. Berdasarkan Tabel 1, tingkat pendidikan ayah balita stunting adalah tamat SMA dan ayah balita tidak stunting yang paling banyak adalah tamat SD, sedangkan tingkat pendidikan ibu balita stunting maupun tidak stunting yang paling dominan adalah tamat SD. Tingkat pendidikan bukan merupakan karakteristik yang dapat memengaruhi stunting secara langsung karena masih banyak faktor-faktor lain yang dapat memengaruhi terjadinya masalah kurang gizi ${ }^{[13]}$. Namun, Ibu yang berpendidikan tinggi akan lebih baik dalam memproses informasi dan belajar untuk memperoleh sebuah pengetahuan sehingga nantinya dapat berkaitan erat dengan wawasan pengetahuannya terkait gizi ${ }^{[14]}$. Sebagian besar ayah balita stunting maupun tidak stunting bekerja sebagai buruh dengan dan rata-rata ibu balita stunting maupun tidak stunting memilih untuk menjadi ibu rumah tangga. Balita dengan ibu tidak bekerja lebih cenderung tidak stunting karena peran ibu sangatlah penting dalam mengurus dan merawat anak serta menentukan kualitas dan kuantitas makanan yang nantinya dikonsumsi oleh anak, namun, faktor lain juga harus diperhatikan seperti tingkat pengetahuan dan pola asuh ibu. 
Tabel 1. Karakteristik Orang Tua dengan Kejadian Stunting di Wilayah Kerja Puskesmas Simolawang, Surabaya, Tahun 2017

\begin{tabular}{|c|c|c|c|c|}
\hline \multirow{2}{*}{ Karakteristik Orang Tua } & \multicolumn{2}{|c|}{ Stunting } & \multicolumn{2}{|c|}{ Tidak Stunting } \\
\hline & $n=33$ & $\%$ & $n=33$ & $\%$ \\
\hline \multicolumn{5}{|l|}{ Pendidikan Ayah } \\
\hline Tidak tamat SD & 3 & 9,1 & 0 & 0,0 \\
\hline Tamat SD & 9 & 27,3 & 14 & 42,4 \\
\hline Tamat SMP & 10 & 30,3 & 9 & 27,3 \\
\hline Tamat SMA & 11 & 33,3 & 9 & 27,3 \\
\hline Tamat Perguruan Tinggi & 0 & 0,0 & 1 & 3,0 \\
\hline \multicolumn{5}{|l|}{ Pendidikan Ibu } \\
\hline Tidak tamat SD & 4 & 12,1 & 1 & 3,0 \\
\hline Tamat SD & 16 & 48,5 & 16 & 48,5 \\
\hline Tamat SMP & 6 & 18,2 & 6 & 18,2 \\
\hline Tamat SMA & 5 & 15,2 & 8 & 24,2 \\
\hline Tamat Perguruan Tinggi & 2 & 6,1 & 2 & 6,1 \\
\hline \multicolumn{5}{|l|}{ Pekerjaan Ayah } \\
\hline PNS & 0 & 0,0 & 0 & 0,0 \\
\hline Pegawai swasta & 5 & 15,2 & 5 & 15,2 \\
\hline ABRI/TNI & 0 & 0,0 & 0 & 0,0 \\
\hline Pedagang/wiraswasta & 10 & 30,3 & 6 & 18,2 \\
\hline Nelayan/petani & 0 & 0,0 & 0 & 0,0 \\
\hline Buruh & 18 & 54,5 & 22 & 66,7 \\
\hline Tidak bekerja & 0 & 0,0 & 0 & 0,0 \\
\hline \multicolumn{5}{|l|}{ Pekerjaan Ibu } \\
\hline PNS & 0 & 0,0 & 0 & 0,0 \\
\hline Pegawai swasta & 3 & 9,1 & 2 & 6,2 \\
\hline ABRI/TNI & 0 & 0,0 & 0 & 0,0 \\
\hline Pedagang/wiraswasta & 6 & 18,2 & 6 & 18,2 \\
\hline Nelayan/petani & 0 & 0,0 & 0 & 0,0 \\
\hline Buruh & 2 & 6,1 & 6 & 18,2 \\
\hline Tidak bekerja & 22 & 66,7 & 19 & 57,6 \\
\hline \multicolumn{5}{|l|}{ Pendapatan } \\
\hline Kuintil 1 & 11 & 33,3 & 7 & 21,2 \\
\hline Kuintil 2 & 8 & 24,2 & 8 & 24,2 \\
\hline Kuintil 3 & 3 & 9,1 & 3 & 9,1 \\
\hline Kuintil 4 & 4 & 12,1 & 10 & 30,3 \\
\hline Kuintil 5 & 7 & 21,2 & 5 & 15,2 \\
\hline
\end{tabular}

Tabel 2. Karakteristik Balita dengan Kejadian Stunting di Wilayah Kerja Puskesmas Simolawang, Surabaya, Tahun 2017

\begin{tabular}{llcccc}
\hline \multirow{2}{*}{ Karakteristik Balita } & \multicolumn{2}{c}{ Stunting } & \multicolumn{2}{c}{ Tidak Stunting } \\
\cline { 2 - 6 } & \multicolumn{2}{c}{$\mathbf{n = 3 3}$} & & $\mathbf{n}=\mathbf{3 3}$ & \multicolumn{1}{c}{$\%$} \\
\hline Jenis Kelamin & & & & & \\
$\quad$ Laki-laki & 12 & 36,4 & 14 & 52,4 \\
$\quad$ Perempuan & 21 & 63,6 & 19 & 37,6 \\
\hline Usia & & & & & \\
24-35 bulan & 10 & 30,3 & 11 & 27,3 \\
36-47 bulan & 9 & 27,3 & 9 & 39,4 \\
48-59 bulan & 14 & 42,4 & 13 & \\
\hline
\end{tabular}


Tabel 3. Hubungan Antara Riwayat Penyakit Diare dan Praktik Higiene dengan Kejadian Stunting di Wilayah Kerja Puskesmas Simolawang, Surabaya, Tahun 2017

\begin{tabular}{|c|c|c|c|c|c|c|}
\hline \multirow[t]{2}{*}{ Variabel yang Diteliti } & \multicolumn{2}{|c|}{ Stunting } & \multicolumn{2}{|c|}{ Tidak Stunting } & \multirow{2}{*}{$\begin{array}{l}\mathrm{p} \\
\text { value }\end{array}$} & \multirow{2}{*}{$\begin{array}{l}\text { OR } \\
(95 \% \mathrm{Cl})\end{array}$} \\
\hline & $n=33$ & $\%$ & $n=33$ & $\%$ & & \\
\hline \multicolumn{7}{|l|}{ Riwayat Penyakit Diare } \\
\hline Diare sering & 24 & 72,2 & 14 & 42,4 & $0,025^{*}$ & 3,619 \\
\hline Diare jarang & 9 & 27,3 & 19 & 57,6 & & $(1,290-10,150)$ \\
\hline \multicolumn{7}{|l|}{ Praktik Higiene } \\
\hline Buruk $(\leq 19)$ & 25 & 75,8 & 13 & 39,4 & $0,006^{*}$ & 4,808 \\
\hline Baik (> 19) & 8 & 24,2 & 20 & 60,6 & & $(1,667-13,862)$ \\
\hline
\end{tabular}

Rata-rata orang tua balita stunting memperoleh penghasilan $\leq \mathrm{Rp} 1.300 .000$, sedangkan rata-rata orang tua balita tidak stunting memperoleh penghasilan yang berkisar antara Rp 1.920.001 - Rp 2.500.000. Berdasarkan penelitian oleh Aramico dkk, semakin tinggi pendapatan keluarga maka semakin tinggi kemungkinan untuk mendapatkan asupan yang cukup sehingga biaya kesakitan akibat kekurangan gizi menjadi berkurang dan pendapatan tersebut bisa digunakan untuk memenuhi kebutuhan makanan di kemudian hari ${ }^{[15]}$.

Kelompok balita stunting maupun tidak stunting memiliki jumlah balita perempuan yang lebih banyak jika dibandingkan dengan balita laki-laki, hal tersebut dapat dilihat pada tabel 2. Dalam kasus ini, jenis kelamin bukan merupakan penyebab langsung terjadinya stunting karena masih banyak faktor lain yang dapat mempengaruhi status gizi seperti kejadian penyakit infeksi, asupan nutrisi, dan lain$\operatorname{lain}^{[15]}$. Namun ada penelitian yang menyebutkan bahwa anak laki-laki lebih diprioritaskan sehingga lebih banyak anak perempuan yang menderita stunting ${ }^{[16]}$. Jumlah balita stunting maupun tidak stunting lebih banyak terdapat pada kelompok usia 4859 bulan. Hal ini terjadi karena pertumbuhan anak terjadi secara optimal mulai dari tahun pertama kehidupan sampai dengan tahun kedua dan kejadian stunting yang terjadi merupakan dampak bersifat kronis yang tampak akibat dari kondisi kurangnya asupan gizi pada saat usia di bawah 25 bulan $^{[6]}$. Pemenuhan asupan gizi yang tidak optimal pada usia 6 sampai 24 bulan dapat terlihat dampaknya pada 1 sampai 3 tahun kemudian dan dapat berlangsung berkepanjangan ${ }^{[17]}$.

Tabel 3 menunjukkan bahwa sebagian besar balita pada kelompok stunting mengalami kejadian diare yang sering yaitu lebih dari dua kali dalam tiga bulan terakhir, sedangkan pada kelompok tidak stunting sebagian besar jarang mengalami diare. Penyakit ini biasanya disebabkan oleh bakteri yang biasa disebut dengan Enteropathogenic Escherichia coli yang juga menjadi penyebab dari terjadinya kematian ribuan anak di negara-negara berkembang tiap tahunnya ${ }^{[18]}$. Diare juga dapat terjadi karena konsumsi makanan atau minuman yang telah terkontaminasi, dari satu orang ke orang lainnya, ataupun dari perilaku higiene yang buruk $^{[18]}$. Berdasarkan hasil wawancara kepada pengasuh balita di wilayah kerja Puskesmas Simolawang, sebagian balita yang terkena diare kemungkinan disebabkan oleh kebiasaan konsumsi makanan sembarangan, seperti sebagian pengasuh masih membeli jajanan tidak berkemasan di pinggir jalan yang tidak jelas kebersihannya dan memberikannya kepada balita. Dalam satu kali diare, rata-rata durasi sakit yang dialami balita adalah berkisar antara 4-7 hari, namun ada juga yang hanya terjadi selama 1 atau 2 hari. Biasanya orang tua atau pengasuh balita membawa balita ke puskesmas dan memberikan balita obat yang telah diberikan oleh puskesmas.

Pada kelompok balita stunting lebih banyak balita yang diasuh dengan higiene yang buruk yaitu dengan persentase $75,8 \%$, sedangkan pada kelompok balita tidak stunting sebagian besar balita diasuh dengan higiene yang baik yaitu dengan persentase $60,6 \%$. Secara umum, lingkungan tempat 
tinggal balita pada kedua kelompok (stunting dan tidak stunting) adalah sama, yang membedakan adalah praktik higiene dari masing-masing keluarga, masih banyak keluarga terutama pada kelompok anak stunting yang memiliki kesadaran yang rendah akan pentingnya kebersihan diri dan lingkungan tempat tinggal. Berdasarkan tabel 4, sebagian besar pengasuh balita masih buruk dalam menjaga kebersihan lingkungan tempat tinggal, kesadaran akan keamanan pangan untuk anak dan kebersihan alat makan masih rendah, masih menggunakan air sumur untuk kebutuhan sehari-hari, dan masih sering membeli cemilan di luar untuk anak.

Berdasarkan hasil uji statistik menggunakan Chi Square, diketahui bahwa ada hubungan yang signifikan antara riwayat penyakit diare dengan kejadian stunting yang dapat dilihat dari nilai $p=0,025(p<0,05)$. Selain itu, diperoleh nilai OR sebesar 3,619 yang artinya adalah balita yang sering mengalami diare berisiko mengalami stunting 3,619 kali lebih besar daripada balita yang jarang mengalami diare di wilayah kerja Puskesmas Simolawang. Penelitian ini sejalan dengan penelitian oleh Dewi dan tim menghasilkan riwayat penyakit infeksi, termasuk diare, merupakan salah satu faktor risiko yang dominan terhadap kejadian stunting $^{[19]}$. Namun, penelitian ini berbeda dengan penelitian oleh Hien dkk di Vietnam dan Kurnia dkk di Makassar bahwa tidak ada hubungan yang signifikan antara penyakit diare dengan kejadian stunting pada balita ${ }^{[20][21]}$.

Praktik higiene yang buruk menimbulkan risiko yang tinggi munculnya bakteri. Bakteri-bakteri ini lah yang akan masuk ke tubuh anak melalui makanan yang biasa disajikan di rumah dan dapat berdampak kepada kesehatan anak tersebut, salah satunya seperti timbulnya penyakit diare dan dapat menyebabkan anak kehilangan cairan serta sejumlah zat gizi yang esensial bagi tubuh $^{[6]}$. Seorang anak yang terkena diare akan mengalami malabsorbsi zat gizi dan durasi diare yang berlangsung lama (lebih dari empat hari) akan membuat anak semakin mengalami kehilangan zat gizi, bila tidak segera ditindaklanjuti dan diimbangi dengan asupan yang sesuai makan terjadi gagal tumbuh $^{[7][22]}$. Anak yang kurang gizi akan memiliki daya tahan tubuh terhadap penyakit yang rendah sehingga mudah terkena penyakit infeksi dan dampak penyakit infeksi ini dapat mempengaruhi perkembangan kognitif anak dan menghambat pertumbuhan badan ${ }^{[23][24]}$. Diare yang terjadi dalam periode yang panjang pada saat balita berusia dua tahun pertama kehidupan dapat berpengaruh terhadap terjadinya retardasi pertumbuhan $^{[25]}$.

Berdasarkan data pada Tabel 3, terdapat hubungan yang signifikan antara praktik higiene dengan kejadian stunting yang dapat dilihat dari nilai $p=0,006(p<0,05)$. Selain itu, dari uji OR diperoleh nilai OR sebesar 4,808 yang artinya adalah balita yang diasuh dengan higiene yang buruk akan berisiko mengalami stunting 4,808 kali lebih besar daripada balita yang diasuh dengan higiene yang baik. Penelitian yang sama juga dilakukan oleh Lestari dkk dengan hasil bahwa terdapat hubungan antara praktik kebersihan dengan kejadian sunting ${ }^{[26]}$. Sebuah penelitian menyebutkan bahwa anak yang diasuh dengan higiene yang buruk akan berisiko 1,447 kali lebih besar dibandingkan dengan anak yang diasuh dalam keadaan higiene yang baik $^{[27]}$.

Hasil yang signifikan dapat disebabkan oleh banyaknya pengasuh balita yang masih menerapkan praktik higiene yang buruk, sehingga dapat berdampak kepada asupan yang dikonsumsi oleh balita. Balita yang mengonsumsi makanan sebagai hasil dari praktik higiene yang buruk dapat meningkatkan risiko anak tersebut terkena penyakit infeksi yang biasa ditandai dengan gangguan nafsu makan, muntah-muntah, ataupun diare sehingga asupan balita tersebut tidak memenuhi kebutuhannya dan kondisi seperti ini yang nantinya akan berimplikasi buruk terhadap pertumbuhan anak ${ }^{[9]}$. Penelitian yang dilakukan Rah dkk juga menyatakan bahwa pengasuh balita dan balita dengan praktik higiene yang baik, seperti mencuci tangan menggunakan sabun setelah melakukan BAB (Buang Air Besar) dan sebelum makan, dapat menurunkan risiko balita terkena stunting sebanyak $14 \%$ dan jika 
mencuci tangan menggunakan sabun sebelum makan anak menurunkan risiko stunting sebanyak $15 \%{ }^{[28]}$. Sebuah penelitian menjelaskan bahwa prilaku higiene yang baik yang dilakukan ibu atau pengasuh alita dapat memberikan efek protektif terhadap kejadian stunting ${ }^{[29]}$.

\section{KESIMPULAN}

Riwayat diare yang terjadi secara sering dalam 3 bulan terakhir dan praktik higiene yang buruk meningkatkan risiko sebesar 3,619 dan 4,808 kali terhadap kejadian stunting pada balita usia 24-59 bulan. Hal yang dapat disarankan adalah adanya pemantauan terkait riwayat penyakit infeksi pada balita oleh posyandu setempat dan diadakan penyuluhan terkait dengan pola asuh pada anak, khususnya praktik higiene, karena pola asuh yang baik dapat berdampak kepada status gizi yang lebih baik. Sebaiknya dilakukan penelitian di masa depan dengan menghubungkan variabel-variabel lainnya yang kemungkinan memiliki kontribusi terhadap kejadian stunting, seperti asupan energi, protein, atau faktor genetik.

\section{ACKNOWLEDGEMENT}

Terima kasih penulis ucapkan kepada kader posyandu di wilayah kerja Puskesmas Simolawang yang telah membantu pada saat pengambilan data.

\section{REFERENSI}

1. Semba RD, De PS, Sun K, Sari M, Akhter $\mathrm{N}$, Bloem MW. Effect of parental formal education on risk of child stunting in indonesia and bangladesh: a cross sectional study. The Lancet Article 2008;371:322-328.

2. WHO. Childhood Stunting: Context, Causes, and Consequences. 2013.

3. Ariyanti SF. 2015. Analisis faktor risiko kejadian stunting pada anak balita di wilayah kerja puskesmas muara tiga kabupaten pidie. Tesis. Medan: Universitas Sumatera Utara;

4. Kementerian Kesehatan RI. Kesehatan Dalam Kerangka Sustainable Development Goals (SDGs).2015.
5. Badan Penelitian Dan Pengembangan Kesehatan Kementerian Kesehatan RI. Riset Kesehatan Dasar 2013. 2013.

6. Welasih BD, Wirjatmadi B. Beberapa faktor yang berhubungan dengan status gizi balita stunting. The Indonesian Journal of Public Health 2012;8(3):99104.

7. Nasikhah R, Margawati A. Faktor risiko kejadian stunting pada balita usia 24-36 bulan di kecamatan semarang timur. Journal of Nutrition College 2012;1(1):176-184.

8. Dinas Kesehatan Pemerintah Kota Surabaya. Profil Kesehatan Kota Surabaya 2015. Surabaya. 2015.

9. MCA. Gambaran Umum Proyek Kesehatan dan Gizi Berbasis Masyarakat (PKGBM) untuk Mencegah Stunting. 2014. Available from http://www.mcaindonesia.go.id/id/home. Diakses pada 16 Maret 2017.

10. Takanashi K, Chonan Y, Quyen DT, Khan NC, Poudel KC, Jimba M. Survey of foodhygiene practices at home and childhood diarrhea in hanoi, vietnam. J Health Popul Nutr 2009;27(5):602-611.

11. Agustina R, Sari TP, Satroamidjojo S, Bovee-Oudenhoven IMJ, Feskens EJM, Kok FJ. Association of food-hygiene practices and diarrhea prevalence among indonesian young children from low socioeconomic urban areas. BMC Public Health 2013;13:977.

12. Kusparlina EP. Hubungan antara umur dan satus gizi ibu berdasarkan ukuran lingkar lengan atas dengan jenis bblr. Journal Penelitian Kesehatan Suara Forike 2016;7(1):21-26.

13. Ni'mah $C$, Muniroh L. Hubungan tingkat pendidikan, tingkat pengetahuan, dan pola asuh ibu dengan wasting dan stunting pada balita keluarga miskin. Media Gizi Indonesia 2015;10(1):84-90.

14. Adriani M, Wirjatmadi B. Gizi dan Kesehatan Balita. Jakarta: Kencana Prenads Media Group; 2014.

15. Aramico B, Sudargo $T$, Susilo J. Hubungan sosial ekonomi, pola asuh, pola makan dengan stunting pada siswa sekolah dasar di kecamatan lut tawar, kabupaten 
aceh tengah. Jurnal Gizi dan Dietetik Indonesia 2013;1(3):121-130.

16. Rosha BCh, Hardinsyah, Baliwati YF. Analisis determinan stunting anak 0-23 bulan pada daerah miskin di jawa tengah dan jawa timur (determinant anlysis of stunting children aged 0-23 months in poor areas in central and east java). Jurnal Penel Gizi Makan 2012;35(1):3441.

17. Sudiman H. Stunting atau pendek: awal perubahan patologis atau adaptasi karena perubahan sosial ekonomi yang berkepanjangan. Media Litbang Kesehatan 2008;18(1): 33-42.

18. WHO. Diarrhoeal Disease. 2013. Available from

http://www.who.int/mediacentre/factsh eets/fs330/en/. Diakses pada 20 April 2017.

19. Dewi IAKC, Adhi KT. Pengaruh konsumsi protein dan seng serta riwayat penyakit infeksi terhadap kejadin stunting pada anak balita usia 24-59 bulan di wilayah kerja puskesmas nusa penida iii. Arc. Com. Health 2016;3(1):36-46.

20. Hien NN. Nutritional status and the characteristic related to malnutrition in children under five years of age in nghean, vietnam. J Prev Med Public Health 2008;41(4): 232-240.

21. Kurnia W, Ibrahim IA, Damayanti DS. Hubungan asupan zat gizi dan penyakit infeksi dengan kejadian stunting anak usia 24-59 bulan di posyandu asoka ii kelurahan barombong kecamatan tamalate kota makassar. Media Gizi Pangan 2016;18(2):70-77.

22. Weisz A, Meuli G, Thakwalakwa C, Trehan I, Maleta K, Manary M. The duration of diarrhea and fever is associated with growth faltering in rural Malawian children aged 6-18 months. Nutrition Journal 2011;10(25).

23. Maxwell, S. Module 5: Cause of Malnutrition. 2011. Available from www.unscn.org . Diakses pada 20 Juni 2017.

24. Walker CLF, Lamberti L, Adair L, Guerrant $R L$, Lescano $A G$, Martorell $R$, Pinkerton $\mathrm{RC}$, Black RE. Does childhood diarrhea influence cognition beyond the diarrheastunting pathway?. PloS ONE 2012;7(10). Available from http://journals.plos.org/plosone/article/fi le $\mathrm{id}=10.1371 /$ journal. pone $.0047908 \&$ ty pe=printable. Diakses pada 23 Juli 2017.

25. Sujendran S, Senarath $U$, Joseph J. Prevalence of stunting among children aged 6 to 36 months, in the eastern province of sri lanka. J Nutr Disorders Ther 2015;5(1).

26. Lestari W, Margawati A, Rahfiludin MZ. Faktor risiko stunting pada anak umur 624 bulan di kecamatan penanggalan kota subulussalam provinsi aceh. Jurnal Gizi Indonesia 2014;3(1): 37-45.

27. Niga DM, Purnomo W. Hubungan antara praktik pemberian makan, perawatan kesehatan, dan kebersihan anak dengan kejadian stunting pada anak usia 1-2 tahun di wilayah kerja puskesmas oebobo kota kupang. Jurnal Wiyata 2016;3(2):151-155.

28. Rah JH, Cronin AA, Baidgayan B, Ahmed SCS. Household Sanitation and Personal Hygiene Practices Are Associated with Child Stunting in Rural India. BMJ Open 2015;5. Available from https://www.researchgate.net/publicatio n/272402323_Household_Sanitation_and _Personal_Hygiene_Practices_Are_Associ ated_with_Child_Stunting_in_Rural_India . Diakses tanggal 24 Maret 2017.

29. Torlesse H, Cronin AA, Sebayang SK, Nandy R. Determinants of stunting in Indonesian children: evidence from a cross-sectional survey indicate a prominent role for the water, sanitation and hygiene sector in stunting reduction. BMC Public Health 2016;16:669.

30. Departemen Kesehatan RI. Sistem Kesehatan Nasional 2004. Jakarta. 2004. 